\title{
Estimates of marine turtle nesting populations in the south-west Indian Ocean indicate the importance of the Chagos Archipelago
}

\author{
Jeanne A. Mortimer, Nicole Esteban \\ Antenor Nestor Guzman and Graeme C. Hays
}

\begin{abstract}
Global marine turtle population assessments highlight the importance of the south-west Indian Ocean region, despite data gaps for the Chagos Archipelago. The archipelago hosts nesting hawksbill Eretmochelys imbricata and green turtles Chelonia mydas, both heavily exploited for 2 centuries until protection in 1968-1970. We assessed available nesting habitat and spatial distribution of nesting activity during rapid surveys of $90 \%$ of the archipelago's coastline in 1996, 1999, 2006 and 2016. We quantified seasonality and mean annual egg clutch production from monthly track counts during 2006-2018 along a $2.8 \mathrm{~km}$ index beach on Diego Garcia island. An estimated 56\% $(132 \mathrm{~km})$ of coastline provided suitable nesting habitat. Diego Garcia and Peros Banhos atolls accounted for $90.4 \%$ of hawksbill and $70.4 \%$ of green turtle nesting. Hawksbill turtles showed distinct nesting peaks during October-February, and green turtles nested year-round with elevated activity during June-October. Estimates of 6,300 hawksbill and 20,500 green turtle clutches laid annually during 2011-2018 indicate that nesting on the Chagos Archipelago has increased 2-5 times for hawksbill turtles and 4-9 times for green turtles since 1996. Regional estimates indicate green turtles produce 10 times more egg clutches than hawksbill turtles, and the Chagos Archipelago accounts for $39-51 \%$ of an estimated $12,500-16$, 00 o hawksbill and $14-20 \%$ of an estimated 104,000-143,500 green turtle clutches laid in the south-west Indian Ocean. The improved status may reflect $>40$ years without significant exploitation. Long-term monitoring is needed to captureinterannual variation in nesting numbers and minimize uncertainty in population estimates.
\end{abstract}

JeanNe A. Mortimer* (Corresponding author, (1) orcid.org/0000-0001-63182890) Department of Biology, University of Florida, Gainesville, Florida 32611, USA, and Turtle Action Group of Seychelles, Victoria, Mahé, Seychelles E-mail jeanne.a.mortimer@gmail.com

NICOLE Esteban ${ }^{*}$ Department of Biosciences, Swansea University, Swansea, UK Antenor Nestor Guzman Naval Facilities Engineering Command Far East Public Works Department, Environmental Office, Diego Garcia, British Indian Ocean Territory

Graeme C. Hays Deakin University, Geelong, Australia

${ }^{*}$ Contributed equally

Received 2 April 2019. Revision requested 16 July 2019.

Accepted 30 August 2019. First published online 10 February 2020.
Keywords Chagos Archipelago, conservation policy, Diego Garcia, global assessments, IUCN Red List, nesting seasonality, regional management unit, threatened species

Supplementary material for this article is available at doi.org/10.1017/So030605319001108

\section{Introduction}

To assess species conservation status, key biological 1 questions focus on population status, trends and spatiotemporal variability (Sutherland et al., 2013b), knowledge of extinction risk or species loss (Sutherland et al., 2013a), as well as how disturbances are altering species distribution and abundance (Parsons et al., 2014). To provide an overarching view of the conservation status of species, the IUCN Red List of Threatened Species often relies on specialist groups to provide systematically collated metrics on population sizes and trends in abundance over time (Barnes et al., 2015). Aspects of the ecology and habitat of a species can make collecting such data difficult (González-Suárez et al., 2012).

Population size is usually determined using methods that include direct sampling (e.g. mark-recapture through tagging) and indirect sampling (e.g. track or clutch observations) but such data may be difficult to obtain for species in remote or inaccessible habitats (e.g. transboundary migrating birds, Bishop et al., 2015; or trans-equatorial migrating basking sharks, Skomal et al., 2009). Direct observation is difficult for marine species that are submerged most of the time, range widely or occur at low densities. For some groups, however, aspects of life history provide windows of opportunity to assess their status. For example, species of seabirds and seals may come ashore and congregate to breed, facilitating collection of extended time series of abundance data (Paleczny et al., 2015; Collins et al., 2016; Trillmich et al., 2016). Marine turtles are another group for which population status is often assessed using annual numbers of nesting females or egg clutch production as indicators (Balazs \& Chaloupka, 2004; SWOT Report, 2017).

In this manner, global and regional populations of all marine turtle species have been assessed since 1996. IUCN categorizes green turtles Chelonia mydas as Endangered 
based on global population declines of $37-61 \%$ over the previous three turtle generations (Seminoff, 2004), and hawksbill turtles Eretmochelys imbricata as Critically Endangered based on a decline of $>80 \%$ using the same criteria (Mortimer \& Donnelly, 2008). Fortunately, marine turtle populations respond well to extended periods of protection at nesting beaches, and population recovery has been documented at multiple sites for both hawksbill and green turtles (Mazaris et al., 2017) and several subpopulations of green turtles have been downlisted by the IUCN Species Survival Commission Marine Turtle Specialist Group. On a global scale, the south-west Indian Ocean, which includes the Chagos Archipelago (hereafter occasionally referred to as Chagos), hosts some of the most important national populations of hawksbill (Mortimer \& Donnelly, 2008) and green turtles (Seminoff, 2004). Genetic studies of both nesting and foraging hawksbill turtles (Mortimer \& Broderick, 1999; Vargas et al., 2016) and nesting green turtles (Bourjea et al., 2015) demonstrate linkages between Chagos and elsewhere in the south-west Indian Ocean, especially Seychelles.

After almost 2 centuries of permanent human settlement and associated exploitation and trade in green turtle meat, hawksbill shell, oil and eggs (Mortimer, 2009; WenbanSmith \& Carter, 2016), the Chagos islands have been uninhabited since 1973 (except Diego Garcia, site of a joint UK/ USA military base). In 2010 one of the largest $\left(640,000 \mathrm{~km}^{2}\right)$ permanent no-take marine protected areas was created within the British Indian Ocean Territory (Koldewey et al., 2010). This presented an opportunity to track the status of remnant marine turtle populations that are no longer exploited. In 1970 J. Frazier visited a few of the islands, interviewed inhabitants, and concluded only a few hundred hawksbill and green turtles remained $(<1,000$ clutches laid annually by each species; Frazier, 1975). In 1996 the first systematic, territory-wide snapshot survey of turtle nesting in Chagos was conducted (49 islands over 6 weeks; Mortimer \& Day, 1999), estimating 300-700 nesting hawksbill (1,200-2,80o clutches) and 400-80o green turtles $(2,200-4,400$ clutches) annually by using seasonality data from Seychelles (Mortimer, 1988; Mortimer \& Bresson, 1999) to extrapolate from the 1996 rapid-survey data. Longterm monitoring was recommended, to define critical habitats, nesting seasonality and long-term population trends.

Recently updated estimates of turtle nesting activity in the region were summarized in SWOT Report (2017) but did not include information about the Chagos Archipelago. Our study aims to remedy this dearth of knowledge relative to elsewhere in the south-west Indian Ocean region. We examined patterns of spatial and seasonal distribution, and abundance of hawksbill and green turtle nesting activity, in the Chagos Archipelago during 1996-2018 and compared our estimates of annual egg clutch production to those reported for sites elsewhere in the region.

\section{Study area}

The Chagos Archipelago comprises c. 67 islands and $235 \mathrm{~km}$ of oceanic coastline distributed across five atolls (Fig. 1, Supplementary Fig. 1; Mortimer \& Day, 1999). These include four groups of outer islands (Table 1): Peros Banhos atoll (36 islands, $80.7 \mathrm{~km}$ of coastline), Salomon atoll (11 islands, $26.3 \mathrm{~km}$ ), Great Chagos Bank (8 islands, $32.9 \mathrm{~km}$ ), and Egmont atoll (5-8 dynamic sand cay islands, c. $22.8 \mathrm{~km}$ ). The main atoll, Diego Garcia, comprises 4 islands with $72.1 \mathrm{~km}$ of coastline (96\% on Diego Garcia island).

The spatial boundaries of the south-west Indian Ocean regional management units for both green and hawksbill turtles have been defined by the IUCN Marine Turtle Specialist Group based on genetic linkages and documented migratory patterns. They include territorial waters of mainland countries from southern Somalia to South Africa plus the islands of Comoros, Madagascar, Mauritius, Mayotte, Réunion and its scattered islands, Seychelles, and the Chagos Archipelago (Wallace et al., 2010).

\section{Methods}

\section{Data collection}

Habitat assessment JAM conducted rapid surveys of the five islanded atolls in 1996, 1999 and 2006, and scored all stretches of surveyed coastline in terms of suitability for nesting based on accessibility of adequate beach sand platform to turtles. Four features of the shoreline were each rated on a scale of $1-4$, with $1-2$ considered accessible, and 3-4 inaccessible: offshore approach, foreshore, high tide line (erosion cliff and associated barriers), and beach platform (see Supplementary Material 1 for detailed criteria). Where any of the four features were scored as 3 or 4 , turtles were unlikely to either successfully emerge onto the beach or to lay eggs. The lengths of suitable (i.e. accessible) oceanic coastline were calculated for each island surveyed, including Diego Garcia (Tables 1 \& 2, Fig. 1).

Spatial distribution of nesting activity amongst atolls Four sets of rapid surveys were conducted: by JAM in 1996, 1999 and 2006, and by NE in 2016. To calculate spatial distribution, JAM conducted rapid surveys in February and March of both 1996 and 2006 across the entire archipelago (Mortimer \& Day, 1999; Mortimer, 2007), and in late January and February of 1999 along the entire oceanic coastline of Diego Garcia atoll (Mortimer, 2000; Table 3, Supplementary Table 1). Data were collected by walking along the perimeter of each island high on the beach platform and recording the locations and characteristics of all turtle tracks and body pits. A track is defined as the imprint a turtle makes when crawling on the sand, and a body pit is 

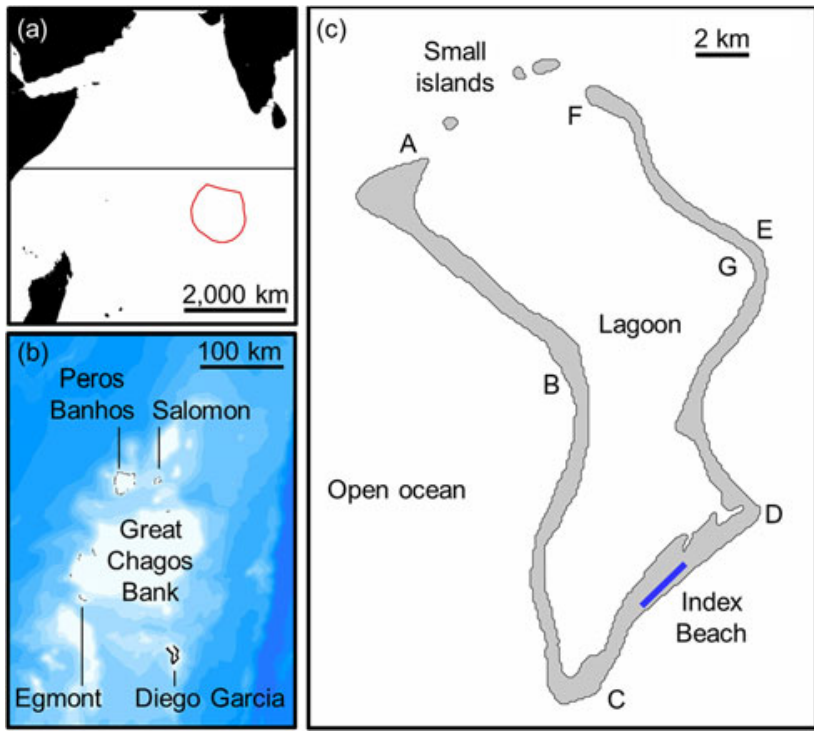

FIG. 1 (a) The location of the Chagos Archipelago in the south-west Indian Ocean with the boundary of the British Indian Ocean Territory, (b) bathymetry of the Archipelago in $100 \mathrm{~m}$ contours (source: GEBCO Compilation Group, 2018), indicating delineation of atolls separated by deep water, and (c) location of $2.8 \mathrm{~km}$ index beach and three small islands on Diego Garcia. Six sections of coastline $(\mathrm{AB}, \mathrm{BC}, \mathrm{CD}, \mathrm{DE}, \mathrm{EF}, \mathrm{FG})$ were surveyed to assess suitable nesting habitat and relative per cent nesting activity by species (Table 2 ).

the large bowl-shaped depression a turtle leaves when digging a nest (Mortimer \& Day, 1999). Tracks can easily be erased during periods of high tide, but body pits, usually dug above the high tide line, can remain visible for weeks, providing a reliable indicator of spatial habitat use, especially when nesting is sparse. All rapid surveys were conducted outside the peak nesting seasons of both species as defined by the results of the present study. A subsample of the coastline (comprising 34 islands and $80 \mathrm{~km}$ ) was surveyed in 1996 and again in 2006 (Mortimer, 2007). During the three rapid surveys conducted in 1996, 1999, and 2006, $211.8 \mathrm{~km}$ (90\% of the Chagos oceanic coastline) were surveyed at least once, and $>80 \mathrm{~km}$ repeatedly (Supplementary Table 1). In 2016 NE surveyed 39 islands $(105 \mathrm{~km})$ by foot and helicopter, to confirm general patterns of spatial distribution.

Assessment of annual egg clutch production and nesting seasonality Along the south-east coast of Diego Garcia island a $2.8 \mathrm{~km}$ long index beach was selected that hosted some of the highest densities of nesting activity identified during the 1999 rapid survey (Mortimer, 2000). Located partially within the Diego Garcia Ramsar Site and adjacent to a paved road, it is easily accessible. Monthly track surveys were conducted by environmental personnel of the US Navy Support Facility and US and UK base personnel volunteers, at 2-week intervals towards the end of neap tides when tracks were least likely to be washed away by high tides. Surveys were during March 2006-April 2007 (14 months), April 2011-May 2013 (26 months) and November 2014March 2018 (41 months). Monthly survey frequencies were 10 months with 3-4 surveys (12.3\%), 45 with 2 (55.6\%), 21 with 1 (25.9\%), and 5 months without surveys (6.2\%). During each survey all tracks were counted, and their widths measured to confirm the species (hawksbill turtle tracks are typically $<95 \mathrm{~cm}$ wide and green turtle tracks $>100 \mathrm{~cm}$ wide; Pritchard \& Mortimer, 1999). To estimate longevity of turtle tracks, fresh tracks of both species were marked and monitored during 27 November-9 December 2018.

\section{Data analysis}

Suitability of nesting habitats Using the habitat accessibility data collected during the rapid surveys of 1996, 1999 and 2006, the amount of suitable habitat for nesting turtles was calculated for each island surveyed, and a mean per cent estimate of suitable habitat was calculated for each atoll (Table 1). For atolls where survey coverage was not $100 \%$ (Peros Banhos and Egmont) mean figures for each atoll were used to estimate suitable habitat along the $9 \%(21 \mathrm{~km})$ of oceanic coastline not surveyed.

Spatial distribution of nesting activity amongst atolls Indices of nesting density were calculated for each species by averaging numbers of body pits per $\mathrm{km}$ of suitable coastline surveyed at each of the four outer-island atolls (Peros Banhos, Salomon, Great Chagos Bank, Egmont) during the 1996 and 2006 surveys, which took place on approximately the same dates in both seasons (Table 3). For each atoll, the mean of the 1996 and 2006 indices were then calculated and multiplied by estimated total $\mathrm{km}$ of suitable habitat to produce indices of relative levels of nesting activity (Table 1). For Diego Garcia, the 1996 and 2006 surveys alone were not adequate to estimate mean total body pits as only 16 and $4 \%$, respectively, of the $72.1 \mathrm{~km}$ coastline were surveyed. In 1999, however, the entire Diego Garcia oceanic coastline was surveyed, and in both 1996 and 2006 the $2.8 \mathrm{~km}$ coastline that became the Diego Garcia index beach had been surveyed. Assuming relatively constant spatial distribution of nesting activity from year to year, we used 1999 data to extrapolate total body pits at Diego Garcia atoll in 1996 and 2006 based on body pit counts recorded at the index beach. For both species, using indices of body pit numbers at all five atolls (Table 1), we calculated per cent contribution of each atoll to total Chagos nesting activity (Table 1 ).

Annual egg clutch production and nesting seasonality Data from monthly track surveys at the index beach were used to estimate monthly total nesting emergences and egg clutches 
TABLE 1 Physical features of each of the five islanded atolls of the Chagos Archipelago (Fig. 1, Supplementary Fig. 1), with numbers of islands, total oceanic coastline and oceanic coastline suitable for nesting. For hawksbill and green turtles, indices of nesting activity were calculated from body pit counts conducted during rapid surveys of all five atolls in 1996 and 2006 and at Diego Garcia in 1999. These indices were used to calculate per cent contribution of each atoll to total Chagos nesting activity. Monthly track surveys on the index beach at Diego Garcia facilitated an estimate of mean annual egg clutches produced at that atoll, and from that to estimate mean annual clutch production at all five atolls.

\begin{tabular}{|c|c|c|c|c|c|c|c|c|c|c|c|c|c|c|c|}
\hline \multirow[b]{3}{*}{ Atoll } & \multirow[b]{3}{*}{$\begin{array}{l}\text { No. of } \\
\text { islands }\end{array}$} & \multirow[b]{3}{*}{$\begin{array}{l}\text { Total } \\
\text { oceanic } \\
\text { coastline } \\
(\mathrm{km})\end{array}$} & \multirow{3}{*}{$\begin{array}{l}\text { Coastline } \\
\text { suitable } \\
\text { for } \\
\text { nesting, } \\
\mathrm{km}(\% \text { of } \\
\text { total) }\end{array}$} & \multicolumn{6}{|c|}{ Hawksbill turtles } & \multicolumn{6}{|c|}{ Green turtles } \\
\hline & & & & \multicolumn{3}{|c|}{$\begin{array}{l}\text { Index of nesting } \\
\text { density }^{1}\end{array}$} & \multicolumn{2}{|c|}{$\begin{array}{l}\text { Relative levels of nesting } \\
\text { activity }\end{array}$} & \multirow[b]{2}{*}{$\begin{array}{l}\text { Estimated } \\
\text { annual } \\
\text { mean egg } \\
\text { clutches }\end{array}$} & \multicolumn{3}{|c|}{$\begin{array}{l}\text { Index of nesting } \\
\text { density }^{1}\end{array}$} & \multicolumn{2}{|c|}{$\begin{array}{l}\text { Relative levels of nesting } \\
\text { activity }\end{array}$} & \multirow[b]{2}{*}{$\begin{array}{l}\text { Estimated } \\
\text { annual } \\
\text { mean egg } \\
\text { clutches }\end{array}$} \\
\hline & & & & 1996 & 2006 & Mean & $\begin{array}{l}\text { Estimated } \\
\text { mean total } \\
\text { body pits }\end{array}$ & $\begin{array}{l}\% \text { of total for } \\
\text { Chagos } \\
(95 \% \text { CI })^{2}\end{array}$ & & 1996 & 2006 & Mean & $\begin{array}{l}\text { Estimated } \\
\text { mean total } \\
\text { body pits }\end{array}$ & $\begin{array}{l}\% \text { of total for } \\
\text { Chagos } \\
(95 \% \mathrm{CI})^{2}\end{array}$ & \\
\hline Peros Banhos & 36 & 80.7 & $41.2(51)$ & 9.0 & 5.9 & 7.5 & 307 & $41.6(38.0-45.2)$ & 2,627 & 5.8 & 12.8 & 9.3 & 383 & $38.8(35.7-41.9)$ & 7,941 \\
\hline Salamon & 11 & 26.3 & $13.9(53)$ & 1.2 & 1.5 & 1.4 & 19 & $2.5(1.4-3.7)$ & 158 & 0.1 & 4.7 & 2.4 & 33 & $3.4(2.2-4.5)$ & 696 \\
\hline Great Chagos Bank & 8 & 32.9 & $18.8(57)$ & 1.0 & 0.6 & 0.8 & 15 & $2.0(1.0-3.1)$ & 126 & 4.5 & 12.4 & 8.5 & 159 & $16.1(13.8-18.4)$ & 3,295 \\
\hline Egmont & 8 & 22.8 & $17.3(76)$ & 1.3 & 3.0 & 2.2 & 37 & $5.0(3.4-6.6)$ & 316 & 6.9 & 4.8 & 5.9 & 101 & $10.2(8.3-12.2)$ & 2,088 \\
\hline Total outer islands & 63 & 162.7 & $91.2(56)$ & & & & & & & & & & & & \\
\hline Diego Garcia & 4 & 72.1 & $40.5(56)$ & 6.6 & 11.2 & 8.9 & 360 & $48.8(45.1-52.5)$ & $3,081^{3}$ & 6.7 & 8.7 & 7.7 & 312 & $31.6(28.6-34.5)$ & $6,467^{3}$ \\
\hline Total Chagos & 67 & 234.8 & $131.7(56)$ & & & & 738 & 100 & 6,308 & & & & 988 & 100 & 20,487 \\
\hline
\end{tabular}

${ }^{1}$ Mean numbers of body pits counted per km of suitable coastline surveyed in 1996 and 2006.

${ }^{2}$ Percentages of total egg clutch production contributed per atoll, calculated by averaging the 1996 and 2006 indices for each atoll and using 1999 survey data to extrapolate to total suitable coastline.

${ }^{3}$ Mean estimated numbers of egg clutches produced annually at Diego Garcia atoll were calculated from monthly track surveys of the Diego Garcia index beach conducted during the 2011-2012 to $2017-2018$ nesting seasons.

${ }^{4}$ Estimated egg clutch production by each species at each of the four outer-island atolls were extrapolated based on calculated spatial distribution of nesting activity. 
TABLE 2 Distribution of suitable nesting habitat and levels of turtle nesting activity recorded during the 1999 rapid survey of $72.1 \mathrm{~km}$ of oceanic coastline, by section, on Diego Garcia (Fig. 1c).

\begin{tabular}{|c|c|c|c|c|}
\hline \multirow[b]{2}{*}{ Section of coastline ${ }^{1}$} & \multirow{2}{*}{$\begin{array}{l}\text { Total } \\
\text { oceanic } \\
\text { coastline } \\
(\mathrm{km})\end{array}$} & \multirow{2}{*}{$\begin{array}{l}\text { Coastline } \\
\text { suitable } \\
\text { for } \\
\text { nesting, } \\
\mathrm{km}(\% \text { of } \\
\text { total) }\end{array}$} & \multicolumn{2}{|c|}{$\begin{array}{l}\% \text { of total nesting } \\
\text { activity }^{2}\end{array}$} \\
\hline & & & $\begin{array}{l}\text { Hawksbill } \\
\text { turtle }\end{array}$ & $\begin{array}{l}\text { Green } \\
\text { turtle }\end{array}$ \\
\hline \multicolumn{5}{|l|}{ Diego Garcia island } \\
\hline $\mathrm{AB}$ (north-west coast) & 16.1 & $9.2(56)$ & 2.4 & 3.9 \\
\hline BC (south-west coast) & 13.1 & $3.0(23)$ & 6.1 & 3.9 \\
\hline $\begin{array}{l}\text { CD (South Point to } \\
\text { Horsburgh Point) }\end{array}$ & 9.8 & $9.4(95)$ & 44.5 & 41.2 \\
\hline $\begin{array}{l}\text { DE (Horsburgh Point to } \\
\text { Cust Point) }\end{array}$ & 12.8 & $8.6(67)$ & 27.0 & 41.8 \\
\hline $\begin{array}{l}\text { EF (Cust Point to Barton } \\
\text { Point) }\end{array}$ & 9.1 & $5.9(65)$ & 17.7 & 5.2 \\
\hline $\begin{array}{l}\text { FG (Inside lagoon: } \\
\text { Barton to Cust Point) }\end{array}$ & 8.2 & $4.1(50)$ & 0.9 & 0.0 \\
\hline Island total & 69.1 & $40.2(58)$ & 98.6 & 96.1 \\
\hline $\begin{array}{l}\text { Index beach (on Diego } \\
\text { Garcia, within CD) }\end{array}$ & 2.8 & $2.8(100)$ & 8.6 & 8.5 \\
\hline \multicolumn{5}{|l|}{ Three small islands } \\
\hline West, Middle, East & 3.0 & $0.3(9)$ & 1.3 & 3.9 \\
\hline $\begin{array}{l}{ }^{2} 29.1 \mathrm{~km} \text { along the outer wes } \\
\text { coast (CD, DE, EF; including } \\
\mathrm{CD}), 8.2 \mathrm{~km} \text { inside the east } \\
\text { the three small islands at the } \\
{ }^{2} \text { Nesting activity recorded in } \\
\text { body pits) are presented as pe }\end{array}$ & $\begin{array}{l}\text { st coast }(\mathrm{AB} \\
\mathrm{g} \text { the } 2.8 \mathrm{~km} \\
\text { coast of the } \\
\text { e mouth of } \\
\text { each section }\end{array}$ & $\begin{array}{l}\text { BC), } 31.8 \mathrm{~km} \\
\text { Diego Garci } \\
\text { lagoon (FG), } \\
\text { the lagoon (F } \\
\text { tof coastline } \\
\text { al nesting act }\end{array}$ & $\begin{array}{l}\mathrm{n} \text { along the o } \\
\text { ia index beac } \\
\text {, and the coas } \\
\text { Fig. 1c). } \\
\text { (based on nu } \\
\text { tivity on Dieg }\end{array}$ & $\begin{array}{l}\text { uter east } \\
\text { h within } \\
\text { stlines of } \\
\text { mbers of }\end{array}$ \\
\hline
\end{tabular}

laid and describe seasonality of nesting activity. For each species mean monthly track counts were calculated. For five unsurveyed months we averaged data from the months before and after. Estimated total numbers of nesting emergences (i.e. turtle tracks) were extrapolated for each month using estimates of track longevity calculated in November-December 2018: for hawksbill turtles 2.8 days (mean $2.79 \pm$ SE 0.2621 , range $=1-7, n=45$ ) and for green turtles 3.9 days ( mean $3.94 \pm \mathrm{SE} 0.4950$, range $=1-9, \mathrm{n}=23$ ). To calculate numbers of egg clutches laid each month at the index beach, we then assumed that $55 \%$ of total turtle tracks resulted in egg laying, based on data from similar habitats in the Seychelles (Mortimer \& Bresson, 1999; Mortimer et al., 2011a). Estimated egg clutches laid annually by hawksbill and green turtles at the index beach were then calculated for each of the following six 12-month (April-March) periods: 2006-2007, 2011-2012, 2012-2013, 2015-2016, 20162017, 2017-2018. These were graphed over time along with an estimate of egg clutches laid annually at the index beach in 1995-1996 based on the mid points of the bracketed estimates derived in 1996 by Mortimer \& Day (1999) and an assumption of consistent spatial distribution of nesting activity over time. Least squares regressions were calculated to provide indications of population trends during

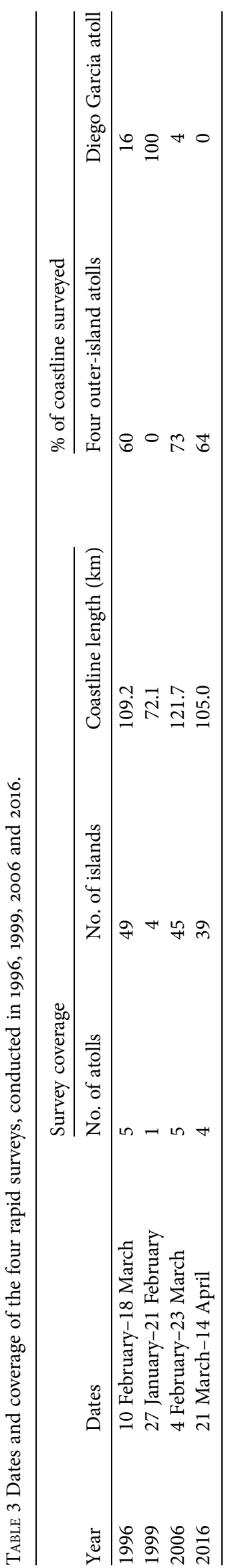


TABLE 4 Sources of data used to estimate the mean annual number of egg clutches produced by hawksbill and green turtles at each site in the south-west Indian Ocean (Fig. 4, Supplementary Table 3).

\begin{tabular}{ll}
\hline Country or & \\
Territory & Source(s) \\
\hline Chagos & This study \\
Archipelago & \\
Seychelles & Mortimer, 1998; Mortimer, 2004; Allen et al., \\
& 2010; Mortimer et al., 2011a, 2011b; Burt \\
& et al., 2015; Mortimer, 2017; Alphonse \\
& Foundation, Bird Island Lodge, Constance \\
& Lémuria Resort, Denis Island Private, \\
& Desroches Foundation, Farquhar Foundation, \\
& Fregate Island Private, Global Vision \\
& International Seychelles, Green Island \\
& Foundation, Island Conservation Society, \\
& J.A. Mortimer, Marine Conservation Society \\
& Seychelles, North Island, Seychelles Ministry \\
of Environment Energy \& Climate Change, & Seychelles Islands Foundation, Seychelles \\
Tanzania & National Parks Authority, Silhouette \\
Fozambique & Foundation, \& WiseOceans, unpubl. data \\
Chapman \& Swinnerton, 1996; Mangar \& \\
Comoros
\end{tabular}

1995-1996 to 2017-2018. As a further indication of population trends, we compared body pit counts made at the same time of year in both 1996 and 2006 along an $80 \mathrm{~km}$ section of coastline. We averaged annual egg clutch production recorded at the index beach during five recent seasons between 2011-2012 and 2017-2018 and extrapolated that mean to the entire Diego Garcia atoll using 1999 data indicating that $8.6 \%$ of hawksbill and $8.5 \%$ of green turtle nesting activity occurred at the index beach (Table 2). Estimated egg clutch production at the four outer atolls was then extrapolated from calculated spatial distribution of body pits (Table 1). To define seasonality and illustrate intra-annual patterns, track counts calculated for each month at the index beach were graphed for each of the six 12-month (April-March) periods along with a graph of the overall monthly means for all six seasons combined. We assessed the relative contribution of Chagos egg clutch production to the south-west Indian Ocean region based on information available in the literature, including SWOT Report (2017). We produced maps of the region indicating estimated annual egg clutch production at each study site included in our review. Exclusive Economic Zone boundary, country border and coastline data (Claus et al., 2018) were projected with ArcMap 10.5.1 (Esri, Redlands, USA). Data sources for each country (or territory) are presented in Table 4 and estimated clutch numbers for individual sites within each country (or territory) in Supplementary Table 3.

\section{Results}

Available habitat and spatial distribution of nesting activity Suitable turtle nesting habitat occurred along $132 \mathrm{~km}$ (58\%) of $235 \mathrm{~km}$ of oceanic coastline, with $51-76 \%$ per atoll (Table 1). For hawksbill turtles per cent of total nesting activity by atoll ranged from $2 \%$ on Great Chagos Bank to $48.8 \%$ on Diego Garcia, and for green turtles from $3.4 \%$ on Salamon to $38.8 \%$ on Peros Banhos (Table 1). Per cent total hawksbill and green turtle nesting activity relative to available habitat at each atoll (Table 1) indicated Diego Garcia and Peros Banhos were the most important atolls in all respects. The 1999 rapid survey results show that at Diego Garcia atoll (Fig. 1c) nesting activity was low along the $29.1 \mathrm{~km}$ western perimeter, hosting only $8.5 \%$ of total hawksbill and $7.8 \%$ of total green turtle nesting on the atoll, compared to $89.2 \%$ of hawksbill and $88.2 \%$ of green turtle nesting along the $31.7 \mathrm{~km}$ eastern perimeter (Table 2). No significant nesting was recorded inside the Diego Garcia lagoon, and little, 1.3\% of hawksbill and 3.9\% of green turtle nesting, at the three small islands.

Annual egg clutch production and population trends We estimated mean annual egg clutch production in Chagos for the period 2011-2012 to 2017-2018 as 6,308 for hawksbill and 20,487 for green turtles (Table 1). Estimated nesting activity at the index beach between 1995-1996 and 2017-2018 showed marked interannual variation but also changes over time (Fig. 2). For green turtles there was a marked, and highly significant, increase in numbers of clutches, with an order of magnitude increase in numbers of clutches per season over the 23 year time series. This increase was best described by a logarithmic function $\left(F_{1,5}=37.2, \mathrm{P}<0.01, r^{2}=0.88\right)$. Hawksbill turtles showed a non-significant increase in numbers of clutches over the time series (for a linear trend $\left.F_{1,5}=0.70, r^{2}=0.12, \mathrm{P}>0.05\right)$. Comparison of body pit counts along the $80 \mathrm{~km}$ of coastline surveyed rapidly in both 1996 and 2006 suggested an increase of 23\% for hawksbill (1996, 91 pits; 2006, 112 pits) and 147\% for green turtles (1996, 167 pits; 2006, 413 pits; Mortimer, 2007). 


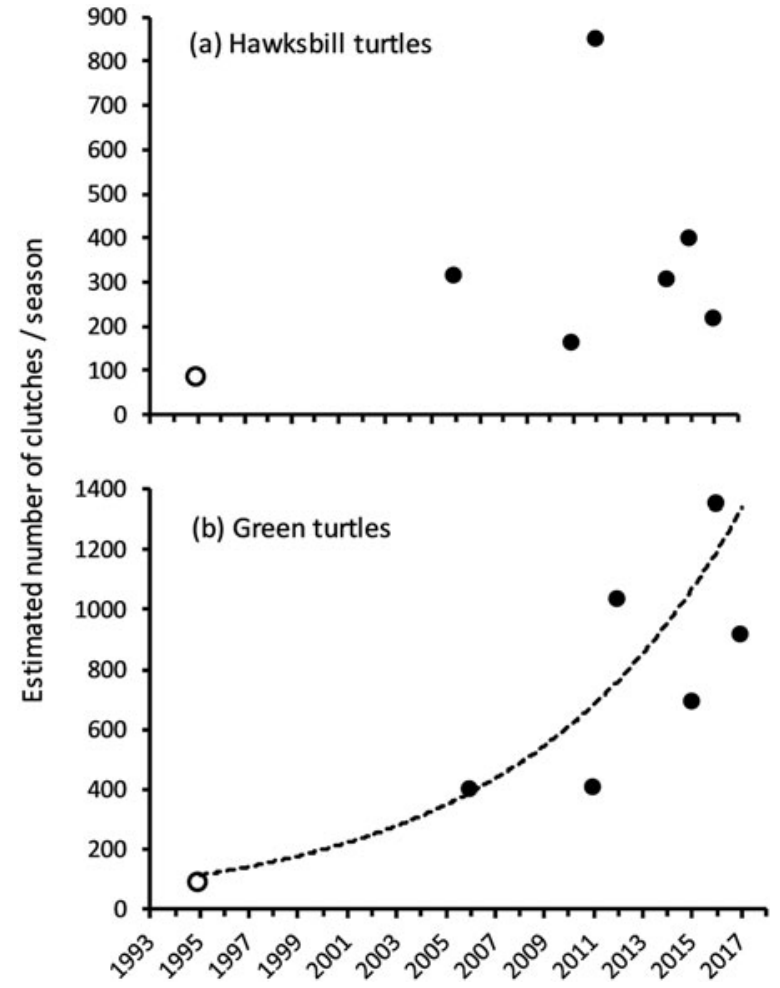

FIG. 2 Estimated annual clutch numbers laid by (a) hawksbill turtles Eretmochelys imbricata and (b) green turtles Chelonia mydas at the $2.8 \mathrm{~km}$ Diego Garcia index beach (Fig. 1c) during 1995-2017. Closed circles represent estimated clutch numbers derived from monthly track surveys conducted in April-March in six periods (2006-2007, 2011-2012, 2012-2013, 2015-2016, 2016-2017 and 2017-2018). Open circles are derived from midpoints of bracketed estimates for 1995-1996 (Mortimer \& Day, 1999). Calculations of least squares regressions showed significant order of magnitude increase in green turtle clutches, as shown by the dashed line in (b).

Seasonality Mean nesting seasonality of Chagos hawksbill turtles indicated $86 \%$ occurred in October-February, with a peak of $28 \%$ in December. Green turtle nesting was more variable, occurring year-round, with $64 \%$ of nesting in June-October, a peak of $19 \%$ in August, and $3-7 \%$ of annual nesting emergences in other months (Fig. 3).

Relative importance of the Chagos Archipelago in the southwest Indian Ocean region Total estimated mean annual reproductive output in the region, at 20 hawksbill and 26 green turtle sites, are 12,466-16,047 hawksbill and 103,944-143,466 green turtle clutches (Supplementary Table 3). Five sites, in Seychelles (Inner Islands, Amirantes), Madagascar (general), and Chagos (Peros Banhos, Diego Garcia), each produce annually 1,001-5,000 hawksbill clutches. Five sites, in Seychelles (Cosmoledo group, Aldabra group), French islands (Europa, Mayotte), and Comoros, each produce $>10,000$ green turtle clutches annually (Fig. 4). The Chagos Archipelago has available
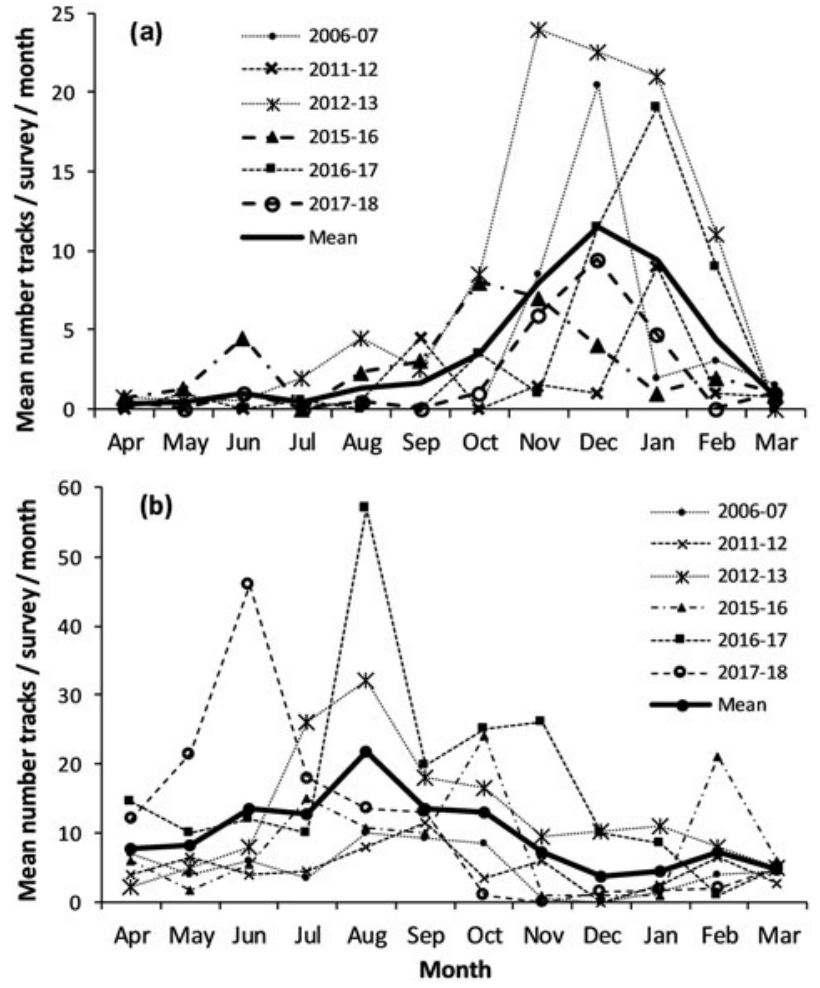

Fig. 3 Monthly distribution of track counts along the $2.8 \mathrm{~km}$ Diego Garcia index beach (Fig. 1c). Dashed lines indicate individual seasons, and solid lines overall mean figures for all seasons combined. (a) Hawksbill turtle nesting peaked in October-February. (b) Green turtles nest year-round with a peak during June-October.

nesting habitat $(132 \mathrm{~km})$ comparable to that of Seychelles (193 km; Supplementary Table 3).

\section{Discussion}

Current estimates of 6,300 hawksbill and 20,500 green turtle clutches laid annually in Chagos represent an increase of $225-525 \%$ for hawksbill and $465-930 \%$ for green turtles since the 1996 surveys, which estimated 1,200-2,800 and 2,200-4,400 clutches, respectively (Mortimer \& Day, 1999). The relatively higher increase for green turtles accords with trends documented at the Diego Garcia index beach during 2006-2018.

Differing patterns of nesting density between atolls probably reflect a combination of ecological factors and historical human impact. The Chagos Archipelago was inhabited by $650-1,200$ coconut plantation labourers who collected wood and caught fish and turtles, beginning in 1776 at Diego Garcia, 1808 at Egmont, and 1813 at Peros Banhos, Salamon and Great Chagos Bank, and ending in 1935 at Egmont and Great Chagos Bank, and in 19711973 at Diego Garcia, Salamon and Peros Banhos (Wenban-Smith \& Carter, 2016; Supplementary Table 2). Current nesting densities may therefore reflect historical 

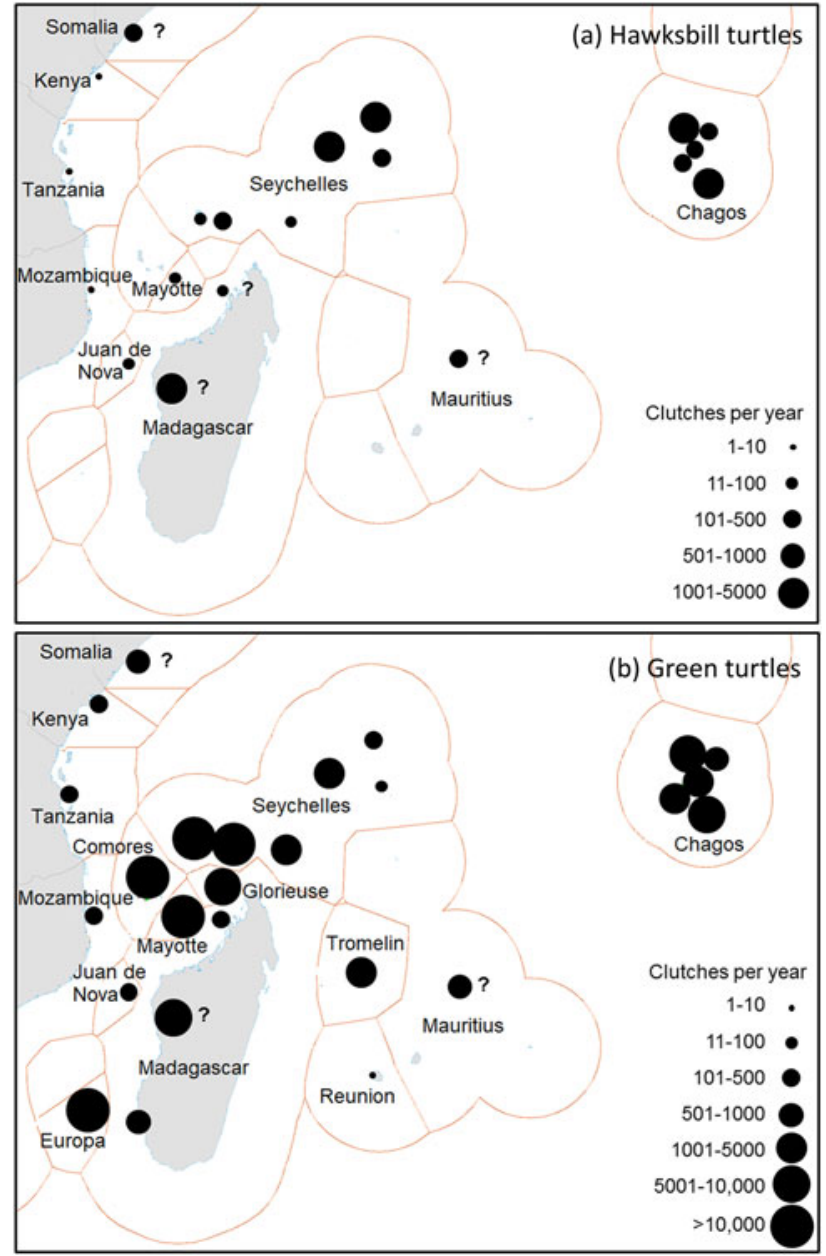

FIG. 4 The most important nesting populations in the south-west Indian Ocean region of (a) hawksbill and (b) green turtles. Circle sizes indicate estimated mean annual egg clutch production. A question mark indicates inadequately surveyed sites. For source data see Table 4 and Supplementary Table 3. The base map is from Claus et al. (2018). The shapes around each population indicate Exclusive Economic Zones.

human exploitation, with higher nesting densities now reported on atolls with relatively less accessible islands.

Peros Banhos and Diego Garcia host most of the nesting habitat and the largest populations of nesting turtles in the Chagos Archipelago. Since 1968 and 1970 green and hawksbill turtles, respectively, have been protected by conservation legislation. Since 1973 turtle protection has been reinforced by several Special Nature Reserves that do not have human habitation or artificial lighting. At Peros Banhos topography affords protection, with abundant habitat on 36 small islands along the rim of the $34 \mathrm{~km}$ diameter lagoon. At both Peros Banhos and Great Chagos Bank, rough seas and primitive sail and oar-driven boats would have limited the efficiency of historical turtle hunts (Wenban-Smith \& Carter, 2016). At many Great Chagos Bank islands the high energy beaches, which offer ideal habitat for green turtles but restrict human access, may explain the abundant green turtle nesting. In contrast, Salamon, with $10.6 \%$ of total nesting habitat, today hosts $<5 \%$ of turtle populations despite reports of abundant turtles in 1786 (Horsburgh, 1809, in Mortimer \& Day, 1999) and 1813 (Wenban-Smith \& Carter, 2016). Salamon comprises a nearly closed island ring, facilitating human access to all nesting beaches regardless of weather. Egmont also has islands easily accessible year-round, but its human population was relatively smaller, and habitation ended 37 years earlier. Today its beaches ( $13.1 \%$ of total) host $16.1 \%$ of the green and $5.0 \%$ of the hawksbill turtles of the archipelago.

The interannual variability of the Diego Garcia monthly surveys typifies nesting populations globally (Broderick et al., 2001) and within the region (Lauret-Stepler et al., 2007; Mortimer, 2012), driven by varying remigration intervals (e.g. Hays, 2000). Individual turtles experience differing environmental conditions year-to-year at their foraging grounds, which modulate the time females take to achieve breeding body condition. So, in some years relatively higher proportions of the population may attain this body condition and migrate to breed. Remigration intervals vary between individuals and even over time for the same individual (Miller, 1997).

The turtle populations of the Chagos Archipelago show signs of recovery after 2 centuries of exploitation. Recovery occurs in two phases. Once protection begins, females that would previously have been killed after only a few nesting attempts now survive the season to produce full complements of clutches and return as re-migrant females in subsequent seasons. This produces an immediate increase in nesting activity and reproductive output even though absolute numbers of adult females have not yet increased (Mortimer, 1985, 1988; Balazs \& Chaloupka, 2004). Then, after a lag of $30-40$ years, the time estimated for IndoPacific hawksbill (Bell \& Pike, 2012) and green turtle (Limpus \& Chaloupka, 1997) hatchlings to attain sexual maturity, a second phase of recovery commences once the offspring produced on protected beaches mature and return as reproductive adults (Dutton et al., 2005). In Seychelles a 40-year recovery pattern has been documented for both hawksbill (Allen et al., 2010) and green turtles (Mortimer et al., 2011b), with up to $800 \%$ increase in clutches after 4 decades of protection. Such recovery is underway in Chagos and we predict will become more evident with continued protection of the marine protected area (Koldewey et al., 2010) and long-term monitoring (Wallace et al., 2011).

The statistically significant increasing trend in the number of green turtles nesting on Chagos is encouraging, and continued monitoring is needed for hawksbill turtles to determine whether the potentially increasing trend is significant or simply reflects interannual variability. The need for long time series to confirm statistical significance of apparent trends in abundance was highlighted by Mazaris et al. (2017) who reported that, globally, many 
time series documenting marine turtle abundance remain non-significant because they are too short. Our estimates of nesting numbers could be further improved. For example, we assumed that $55 \%$ of total turtle tracks resulted in egg laying based on data from Seychelles, but this assumed value, central to our calculations, could be improved by collecting data on rates of egg-laying success across the Chagos Archipelago. Some of the other values we used in our estimates are probably more robust. For example, our 95\% confidence interval of $0.286-0.345$ for the proportion of total observed Chagos green turtle body pits occurring on Diego Garcia enables us to conclude confidently that Diego Garcia hosts a large proportion of all green turtle clutches across the archipelago. Future status assessments may be improved by new methodologies, such as ongoing research on the archipelago deploying cameras to photograph daily tracks on beaches. Any inaccuracies our sampling imposed on estimates of nesting activity would probably add noise and so dampen any real trends, rather than generate spurious trends. Hence, we are confident that our calculated increase in numbers of green turtle clutches since 1996 is real, a pattern mirrored in other rookeries elsewhere (e.g. Mazaris et al., 2017).

Another threat to turtle rookeries is the presence of non-native rats Rattus spp., which prey on hatchlings (Caut et al., 2008) and embryos (JAM, unpubl. data from Diego Garcia) and disrupt both terrestrial and marine ecosystems (Graham et al., 2018). Ongoing and planned rat eradication in the Chagos Archipelago (Hilton \& Cuthbert, 2010) will most likely accelerate turtle recovery.

Our study is the first to document nesting seasonality at Chagos, following earlier snapshot surveys (Frazier, 1975; Mortimer \& Day, 1999; Mortimer, 2000, 2007). The October-February nesting peak exhibited by hawksbill turtles on Diego Garcia corresponds to that in Seychelles, where 94 and $98 \%$ of annual nesting occurs during October-February in the inner islands (Mortimer \& Bresson, 1999) and Amirantes (Mortimer et al., 2011a), respectively, coincident with high north-west monsoon precipitation (Mortimer \& Bresson, 1999). Green turtles typically nest year-round throughout the region (Dalleau et al., 2012), with patterns of high intra- and interannual variation (Mortimer et al., 2011a; Mortimer, 2012). The June-October (austral winter) nesting peak on Diego Garcia accords with comparative data from the region, suggesting a tendency for lower latitude nesting to peak in the austral autumn and winter, and higher latitude nesting in the austral summer, a pattern indicating that temperature may be moderating seasonality (Dalleau et al., 2012; Mortimer, 2012). Across species and ocean basins the slope of the relationship between temperature and date of first breeding is steeper at higher latitudes (Mazaris et al., 2013). Variations in environmental parameters (e.g. sea surface temperature) forming part of global climate change (IPCC, 2014) are associated with shifts in timing of seasonal events for a range of organisms (Walther et al., 2002; Ramp et al., 2015), including earlier onset of nesting in loggerhead turtles Caretta caretta (Hawkes et al., 2007). Further investigation of seasonality in the Chagos Archipelago may also reveal variations in peak nesting amongst the five atolls.

Our review of mean annual egg clutch production in the south-west Indian Ocean indicates that the Chagos Archipelago accounts for $39-51 \%$ of hawksbill and $14-20 \%$ of green turtle reproduction in the region. The Red List assessment criteria focus on annual numbers of nesting females, but we suggest egg clutch production is a more meaningful statistic given lack of consensus amongst turtle researchers regarding within season clutch frequency. Estimates of 3-5 clutches for hawksbill turtles (Mortimer \& Donnelly, 2008) accord with data from Seychelles (Mortimer \& Bresson, 1999) but an estimate of 3 clutches for green turtles (Seminoff, 2004) is probably an underestimate. Esteban et al. (2017) recorded a minimum mean of 6.0 clutches per turtle by satellite tracking inter-nesting female green turtles at Diego Garcia. It follows that although green turtle populations in the region produce almost 10 times more egg clutches than hawksbill turtle populations, there may be only five times as many female green turtles nesting annually. The Seychelles-Chagos hawksbill turtle population, identified by genetics as a separate regional management unit (Vargas et al., 2016), accounts for $97 \%$ of known hawksbill turtle nesting in the region. Linkage of the Chagos Archipelago to the region is also supported by migrations of most satellite-tracked post-nesting Chagos green turtles to Seychelles, Madagascar and eastern Africa (Hays et al., 2014). The Chagos Archipelago is, however, situated at the interface of the south-west Indian Ocean region and the IUCN Marine Turtle Specialist Group-designated north-west Indian Ocean regional management unit (Wallace et al., 2010). Evidence of a Chagos/north-west Indian Ocean linkage is therefore expected. Three of eight post-nesting Chagos green turtles migrated to the north-west Indian Ocean sites of Maldives and northern Somalia (Hays et al., 2014), and the possibility that some immature hawksbill turtles foraging in Chagos have genetic links with the Arabian Peninsula (Mortimer \& Broderick, 1999) warrants further investigation. Our understanding of marine turtle populations in the wider western Indian Ocean region is improving, and conservation managers need to use these findings to work across international boundaries to protect marine turtles at nesting habitats and foraging sites. Our findings demonstrate the importance of the Chagos Archipelago to nesting turtles at both a regional and global scale. The marine protected area can be expected to help ensure long-term protection of these resources.

Acknowledgements This work was supported by the Bertarelli Foundation as part of the Bertarelli Programme in Marine Science. We are grateful to C.R.C. Sheppard and members of the 1996 and 
2006 Chagos Research Expeditions, both funded by the UK Foreign \& Commonwealth Office with contributions from the Fauna \& Flora International 100\% Fund in 1996, and the U.S. Fish \& Wildlife Service Multinational Species Conservation Fund (98210-6-G073) in 2006. The 1999 Diego Garcia survey was implemented in collaboration with Fauna \& Flora International, funded by the UK Overseas Territories Programme. The Bertarelli Foundation facilitated the 2016 rapid surveys. Monthly track counts on the Diego Garcia index beach during 2006-2018 were assisted by K. Dunn, K. Corson and many volunteers. Travel and logistical support were provided by a Darwin Initiative Challenge Fund grant (EIDCF008), the UK Department of the Environment Food and Rural Affairs, the UK Foreign \& Commonwealth Office, College of Science of Swansea University, and the British Indian Ocean Territory Scientific Advisory Group of the Foreign \& Commonwealth Office. The authors acknowledge use of Maptool (seaturtle.org) for production of Fig. 1.

Author contributions Study design: JAM, NE, GCH; rapid-survey fieldwork: JAM in 1996, 1999, 2006, NE in 2016; design and inception of index beach monthly surveys: JAM; implementation of monthly surveys: ANG; data compilation, analysis and writing: JAM, NE, with contributions from all authors.

\section{Conflicts of interest None.}

Ethical standards This research abided by the Oryx guidelines on ethical standards, was non-intrusive, and approved by Swansea University Ethics Committee and the British Indian Ocean Territory Administration of the UK Foreign and Commonwealth Office. All necessary permits were obtained for conducting research in British Indian Ocean Territory.

\section{References}

Allen, Z.C., Shah, N.J., Grant, A., Derand, G-D. \& Bell, D. (2010) Hawksbill turtle monitoring in Cousin Island Special Reserve, Seychelles: an eight-fold increase in annual nesting numbers. Endangered Species Research, 11, 195-200.

Balazs, G.H. \& Chaloupka, M. (2004) Thirty-year recovery trend in the once depleted Hawaiian green sea turtle stock. Biological Conservation, 117, 491-498.

Barnes, M., Szabo, J.K., Morris, W.K. \& Possingham, H. (2015) Evaluating protected area effectiveness using bird lists in the Australian Wet Tropics. Diversity and Distributions, 21, 368-378.

Bell, I. \& Pike, D.A. (2012) Somatic growth rates of hawksbill turtles Eretmochelys imbricata in a northern Great Barrier Reef foraging area. Marine Ecology Progress Series, 446, 275-283.

Bishop, C.M., Spivey, R.J., Hawkes, L.A., Batbayar, N., Chua, B., Frappell, P.B. et al. (2015) The roller coaster flight strategy of bar-headed geese conserves energy during Himalayan migrations. Science, 347, 250-254.

Bourjea, J., Ciccione, S. \& Ratsimbazafy, R. (2006) Marine turtle surveys in Nosy Iranja Kely, north-western Madagascar. Western Indian Ocean Journal of Marine Science, 5, 209-212.

Bourjea, J., Frappier, J., Quillard, M., Ciccione, S., Roos, S., Hughes, G. \& Grizel, H. (2007) Mayotte Island: another important green turtle nesting site in the southwest Indian Ocean. Endangered Species Research, 3, 273-282.

Bourjea, J., Mortimer, J.A., Garnier, J., Okemwa, G., Godley, B.J., Hughes, G. et al. (2015) Population structure enhances perspectives on regional management of the western Indian Ocean green turtle. Conservation Genetics, 16, 1069-1083.

Broderick, A.C., Godley, B.J. \& Hays, G.C. (2001) Trophic status drives inter-annual variability in nesting numbers of marine turtles. Proceedings of the Royal Society of London B, 268, 1481-1487.

Burt, A.J., Dunn, N., Mason-Parker, C., Antha, S. \& Mortimer, J.A. (2015) Curieuse National Park, Seychelles: critical management needs for protection of an important nesting habitat. Marine Turtle Newsletter, 147, 6-11.

Caut, S., Angulo, E. \& Courchamp, F. (2008) Dietary shift of an invasive predator: rats, seabirds and sea turtles. Journal of Applied Ecology, 45, 428-437.

Chapman, R. \& Swinnerton, K.J. (1996) The Mauritius Wildlife Fund St. Brandon Expedition: 22 Jan 1996 to 6 Feb 1996. Unpublished report. Mauritius Wildlife Fund, Mauritius.

Ciccione, S. \& Bourjea, J. (2006) Nesting of green turtles in Saint-Leu, Reunion Island. Marine Turtle Newsletter, 112, 1-3.

Ciccione, S. \& Bourjea, J. (2010) Nesting beach revegetation and its influence on green turtle (Chelonia mydas) conservation in Reunion Island. Indian Ocean Turtle Newsletter, 11, 50-52.

Claus, S., De Hauwere, N., Vanhoorne, B., Souza Dias, F., Oset García, P., Schepers, L. et al. (2018) Marine Regions.

marineregions.org [accessed 14 November 2018].

Collins, C.J., Chilvers, B.L., TAylor, M. \& Robertson, B.C. (2016) Historical population size of the threatened New Zealand sea lion Phocarctos hookeri. Journal of Mammology, 97, 436-443.

Dalleau, M., Ciccione, S., Mortimer, J.A., Garnier, J., Benhamou, S. \& Bourjea, J. (2012) Nesting phenology of marine turtles: insights from a regional comparative analysis on green turtle (Chelonia mydas). PLOS ONE, 7, e46920.

Derville, S., Jean, C., Dalleau, M., Le Gall, J-Y., Ciccione, S. \& BOURJEA, J. (2015) Long-term monitoring of green turtle nesting on Tromelin Island demonstrates stable reproduction and population parameters. Chelonian Conservation and Biology, 14, 11-20.

DUnBAR, T. (2011) Monitoring nesting trends and hatchling success of the green turtle (Chelonia mydas) population on Mnemba Island, Zanzibar. Independent Study Project (ISP) Collection. 1006. digitalcollections.sit.edu/isp_collection/1006 [accessed 7 December 2019].

Dutton, D.L., Dutton, P.H., Chaloupka, M. \& Boulon, R.H. (2005) Increase of a Caribbean leatherback turtle Dermochelys coriacea nesting population linked to long-term nest protection. Biological Conservation, 126, 186-194.

Esteban, N., Mortimer, J.A. \& Hays, G.C. (2017) How numbers of nesting sea turtles can be overestimated by nearly a factor of two. Proceedings of the Royal Society B, 280, 20162581.

Fernandes, R.S., Williams, J. \& Trinidade, J. (2016) Monitoring, Tagging and Conservation of Marine Turtles in Mozambique: Annual Report 2015/16. Centro Terra Viva, Maputo, Mozambique.

Frazier, J. (1975) Marine turtles of the Western Indian Ocean. Oryx, 13, 164-175.

Frazier, J. (1985) Marine Turtles in the Comoro Archipelago. North-Holland Publishing Company, New York, USA.

Garnier, J., Hill, N., Guissamulo, A., Silva, I., Witt, M. \& Godley, B. (2012) Status and community-based conservation of marine turtles in the northern Querimbas Islands (Mozambique). Oryx, 46, 359-367.

GEBCO Compilation Group (2018) General Bathymetric Chart of the Oceans 2018 Grid. dx.doi.org/10.5285/836fo16a-33be-6ddc-e0536c86abco788e [accessed November 2018].

González-Suárez, M., Lucas, P.M. \& Revilla, E. (2012) Biases in comparative analyses of extinction risk: mind the gap. Journal of Animal Ecology, 81, 1211-1222. 
Graham, N.A.J., Wilson, S.K, Carr, P., Hoey, A.S., Jennings, S. \& MACNEIL, M.A. (2018) Seabirds enhance coral reef productivity and functioning in the absence of invasive rats. Nature, 559, 250-253.

Hawkes, L.A., Broderick, A.C., Coyne, M.S., Godfrey, M.H. \& Godley, B.J. (2007) Only some like it hot-quantifying the environmental niche of the loggerhead sea turtle. Diversity and Distributions, 13, 447-457.

HAYs, G.C. (2000) The implications of variable remigration intervals for the assessment of population size in marine turtles. Journal of Theoretical Biology, 206, 221-227.

Hays, G.C., Mortimer, J.A., Ierodiaconou, D. \& Esteban, N. (2014) Use of long-distance migration patterns of an endangered species to inform conservation planning for the world's largest marine protected area. Conservation Biology, 28, 1636-1644.

Hilton, G.M. \& Cuthiert, R.J. (2010) The catastrophic impact of introduced mammalian predators on birds of the United Kingdom Overseas Territories: a review and synthesis. Ibis, 152, 443-458.

iPCC (Intergovernmental Panel on Climate Change) (2014) Observed changes and their causes. In Climate Change 2014: Synthesis Report (eds R.K. Pachauri \& L.A. Meyer), pp. 39-54. IPCC, Geneva, Switzerland.

Jean, C., Ciccione, S., Bourjea, J. \& Dalleau, M. (2017) Sea Turtle Nesting in French Southern Territories. Personal communication, cited in SWOT Report (2017).

Joynson Hicks, C. \& West, L. (2017) Sea Turtle Nesting in Tanzania. Personal communication, cited in SWOT Report (2017).

Koldewey, H.J., Curnick, D., Harding, S., Harrison, L.R. \& Gollock, M. (2010) Potential benefits to fisheries and biodiversity of the Chagos Archipelago/British Indian Ocean Territory as a no-take marine reserve. Marine Pollution Bulletin, 6o, 1906-1915.

Lauret-Stepler, M., Bourjea, J., Roos, D., Pelletier, D., Ryan, P.G., Ciccione, S. \& Grizel, H. (2007) Reproductive seasonality and trend of Chelonia mydas in the SW Indian Ocean: a 20 yr study based on track counts. Endangered Species Research, 3, 217-227.

Lauret-Stepler, M., Ciccione, S. \& Bourjea, J. (2010) Monitoring of marine turtles reproductive activities in Juan de Nova, Eparses Islands, South Western Indian Ocean, based on track counts and width. Indian Ocean Turtle Newsletter, 11, 18-24.

LE GALL, J.Y. (1988) Biologie et évaluation des populations de tortues vertes Chelonia mydas des atolls Tromelin et Europa (Océan Indien S.O.). Mésogée, 48, 33-42.

Le Gall, J.Y., Bosc, P., Château, D. \& Taquet, M. (1986) Estimation du nombre de tortues vertes femelles adultes Chelonia mydas par saison de ponte à Tromelin et Europa (Océan Indien) (1973-1985). Océanographie Tropicale, 21, 3-22.

Limpus, C.J. \& Chaloupka, M. (1997) Nonparametric regression modelling of green sea turtle growth rates (southern Great Barrier Reef). Marine Ecology-Progress Series, 149, 23-24.

MAngar, V. \& Chapman, R. (1996) The status of sea turtle conservation in Mauritius. In Status of Sea Turtle Conservation in the Western Indian Ocean (eds S.L. Humphrey \& R. Salm), pp. 121124. Regional Seas Reports and Studies No. 165. United Nations Environment Programme, Nairobi, Kenya.

Mazaris, A.D., Kallimanis, A.S., Pantis, J.D. \& Hays, G.C. (2013) Phenological response of sea turtles to environmental variation across a species' northern range. Proceedings of the Royal Society $B, 280,1-9$.

Mazaris, A.D., Schofield, G., Gkazinou, C., Almpanidou, V. \& HAys, G.C. (2017) Global sea turtle conservation successes. Science Advances, 3, e1600730.

Miller, J.D. (1997) 3. Reproduction in sea turtles. In The Biology of Sea Turtles (eds P.L. Lutz \& J.A. Musick), pp. 51-81, CRC Press, Boca Raton, USA.
Mortimer, J.A. (1985) Recovery of green turtles on Aldabra. Oryx, $19,146-150$.

Mortimer, J.A. (1988) Green turtle nesting at Aldabra Atollpopulation estimates and trends. Bulletin of the Biological Society of Washington, 8, 116-128.

Mortimer, J.A. (1998) Turtle \& Tortoise Conservation. Project J1: Environmental Management Plan of the Seychelles. Final report to the Ministry of Environment Republic of Seychelles and the Global Environment Facility, Seychelles.

Mortimer, J.A. (200o) Diego Garcia Marine Turtle Conservation Assessment (British Indian Ocean Territory). Unpublished report to British Indian Ocean Territory Department, Environment Science \& Energy Department, and Foreign \& Commonwealth Office, London, UK.

Mortimer, J.A. (2002) A Strategy to Conserve and Manage the Sea Turtle Resources of the Western Indian Ocean Region. A report produced for IUCN, WWF, and the Ocean Conservancy. ioseaturtles.org/eleclib/WIOStrategyJMortimer.pdf [accessed 11 September 2018].

Mortimer, J.A. (2004) Seychelles Marine Ecosystem Management Project (SEYMEMP): Turtle Component. Final report to the Ministry of Environment and Natural Resources Republic of Seychelles and the Global Environment Facility, Seychelles.

Mortimer, J.A. (2007) Status \& Conservation of Nesting Turtles in the Chagos Islands (BIOT). Unpublished report to U.S. Fish \& Wildlife Service Multinational Species Conservation Fund (Award 98210-6-Go73). Washington, DC, USA.

Mortimer, J.A. (2009) History of turtle exploitation in Chagos. Chagos News, 34, 14-16. chagos-trust.org/images/uploads/ documents/Chagos_News_34.pdf [accessed 10 September 2018].

Mortimer, J.A. (2012) Seasonality of green turtle (Chelonia mydas) reproduction at Aldabra Atoll, Seychelles (1980-2011) in the regional context of the Western Indian Ocean. Chelonian Conservation and Biology, 11, 170-181.

Mortimer, J.A. (2017) Community Monitoring of Nesting Sea Turtles at D'Arros and St. Joseph, Seychelles: Turtle Track Count Analysis for 13 Seasons (2004-05 to 2016-17). Unpublished report. Save Our Seas Foundation, Geneva, Switzerland.

Mortimer, J.A. \& Bresson, R. (1999) Temporal distribution and periodicity in hawksbill turtles (Eretmochelys imbricata) nesting at Cousin Island, Republic of Seychelles, 1971-1997. Chelonian Conservation and Biology, 3, 292-298.

Mortimer, J.A. \& Broderick, D. (1999) Population genetic structure and developmental migrations of sea turtles in the Chagos Archipelago and adjacent regions inferred from mtDNA sequence variation. In Ecology of the Chagos Archipelago (eds C.R.C. Sheppard \& M.R.D. Seaward), pp. 185-194, Linnean Society Occasional Publications 2, London, UK.

Mortimer, J.A., Camille, J.-C. \& Boniface, N. (2011a) Seasonality and status of nesting hawksbill (Eretmochelys imbricata) and green turtles (Chelonia mydas) at D'Arros Island, Amirantes Group, Seychelles. Chelonian Conservation and Biology, 10, 26-33.

Mortimer, J.A. \& Day, M. (1999) Sea turtle populations and habitats in the Chagos Archipelago, British Indian Ocean Territory. In Ecology of the Chagos Archipelago (eds C.R.C. Sheppard \& M.R.D. Seaward), pp. 159-176. Linnean Society Occasional Publications 2, London, UK.

Mortimer, J.A. \& Donnelly, M. (2008) Eretmochelys imbricata. In The IUCN Red List of Threatened Species. dx.doi.org/10.2305/ IUCN.UK.2008.RLTS.T8005A12881238.en [accessed 3 September 2018].

Mortimer, J.A., von Brandis, R.G., Liljevik, A., Chapman, R. \& Collie, J. (2011b) Fall and rise of nesting green turtles (Chelonia mydas) at Aldabra Atoll, Seychelles: positive response to four 
decades of protection (1968-2008). Chelonian Conservation and Biology, 10, 165-176.

Oкемwa, G.M., Nzuki, S, \& Muenis, E.M. (2004) The status and conservation of sea turtles in Kenya. Marine Turtle Newsletter, $105,1-6$.

Olendo, M.I., Okemwa, G.M., Munga, C.N., Mulupi, L.K., Mwasi, L.D., Mohamed, H.B. et al. (2019) The value of long-term, community-based monitoring of marine turtle nesting: a study in the Lamu archipelago, Kenya. Oryx, 53, 71-80.

Paleczny, M., Hammill, E., Karpouzi, V. \& Pauly, D. (2015) Population trend of the world's monitored seabirds, 1950-2010. PLOS ONE, 10, eo129342.

Parsons, E.C.M., Favaro, B., Aguirre, A.A., Bauer, A.L., Blight, L.K., Cigliano, J.A. et al. (2014) Seventy-one important questions for the conservation of marine biodiversity. Conservation Biology, 28, 1206-1214.

Pritchard, P.C.H. \& Mortimer, J.A. (1999) Taxonomy, external morphology, and species identification. In Management and Research Techniques for the Conservation of Sea Turtles (eds K.L. Eckert, K.A. Bjorndal, F.A. Abreu-Grobois \& M. Donnelly), pp. 21-38. IUCN/SSC Marine Turtle Specialist Group Publication No. 4, Blanchard, USA.

Quillard, M. \& Ballorain, K. (2017) Sea Turtles Nesting in Mayotte. Personal communication, cited in SWOT Report (2017).

Rakotonirina, B. \& Cooke, A. (1994) Sea turtles of Madagascartheir status, exploitation and conservation. Oryx, 28, 51-61.

Ramp, C., Delarue, J., Palsbøll, P.J., Sears, R. \& Hammond, P.S. (2015) Adapting to a warmer ocean - seasonal shift of baleen whale movements over three decades. PLOS ONE, 10, eo121374.

Seminoff, J.A. (2004) Chelonia mydas. In The IUCN Red List of Threatened Species. dx.doi.org/10.2305/IUCN.UK.2004.RLTS. T4615A11037468.en [accessed 3 September 2018].

Skomal, G.B., Zeeman, S.I., Chisholm, J.H., Summers, E.L., Walsh, H.J., McMahon, K.W. et al. (2009) Transequatorial migrations by basking sharks in the Western Atlantic Ocean. Current Biology, 19, 1019-1022.
Sutherland, W.J., Bardsley, S., Clout, M., Depledge, M.H., Dicks, L.V., Fellman, L. et al. (2013a) A horizon scan of global conservation issues for 2013. Trends in Ecology and Evolution, $28,16-22$

Sutherland, W.J., Freckleton, R.P., Godfray, H.C.J., Beissinger, S.R., Benton, T., Cameron, D.D. et al. (2013b) Identification of 100 fundamental ecological questions. Journal of Ecology, 101, 58-67.

SWOT Report (2017) State of the World's Sea Turtles. XII. seaturtlestatus.org/sites/swot/files/report/SWOT\%2oReport_12.pdf [accessed 9 September 2018].

Trillmich, F., Meise, K., Kalberer, S., Mueller, B., Piedrahita, P., Pörschman, U. et al. (2016) On the challenge of interpreting census data: insights from a study of an endangered pinniped. PLOS ONE, 11, e0154588.

UNEP-WCMC (2010) The Marine Turtle Interactive Mapping System (IMAPS): Green Turtle Nesting Data. stort.unep-wcmc.org/ imaps/IndTurtles/viewer.htm [accessed 2010].

Vargas, S.M., Jensen, M.P., Ho, S.Y.W., Mobaraki, A., Broderick, D., Mortimer, J.A. et al. (2016) Phylogeography, genetic diversity, and management units of hawksbill turtles in the Indo-Pacific. Journal of Heredity, 107, 199-213.

Wallace, B.P., DiMatteo, A.D., Bolten, A.B., Chaloupka, M.Y., Hutchinson, B.J., Abreu-Grobois, F.A., Mortimer, J.A. et al. (2011) Global conservation priorities for marine turtles. PLOS ONE, 6, e24510.

Wallace, B.P., DiMatteo, A.D., Hurley, B.J., Finkbeiner, E.M., Bolten, A.B., Chaloupka, M.Y. et al. (2010) Regional management units for marine turtles: a novel framework for prioritizing conservation and research across multiple scales. PLOS ONE, 5, e15465. Walther, G.-R., Post, E., Convey, P., Menzel, A., Parmesan, C., B BEBEE, T.J.C. et al. (2002) Ecological responses to recent climate change. Nature, 416, 389-395.

Wenban-Smith, N. \& Carter, M. (2016) Chagos: a HistoryExploration, Exploitation, Expulsion. Chagos Conservation Trust, Sandy, UK. 